\title{
KRITIK PRAGMATISME RICHARD RORTY TERHADAP EPISTEMOLOGI BARAT MODERN
}

\section{Yuventia Prisca Kalumbang}

Institut Teknologi Kreatif Bina Nusantara Malang

Email: yuventia.kalumbang@binus.edu ; yprisca08@gmail.com

\section{Abstrak}

Tulisan ini fokus menjelaskan dua perkara pokok, yakni ciri-ciri umum pragmatisme dan fungsi filsafat di dalam khazanah pragmatisme yang digagas oleh filsuf asal Amerika Serikat abad 20-21: Richard Rorty. Penulisan ini bertumpu kepada metode kepustakaan yang mengkaji pemikiran-pemikiran pragmatisme Rorty dalam bukunya yang masyur: Philopsohy and the Mirror of Nature. Bagi Rorty, pragmatisme adalah sebuah orientasi filsafat baru yang melampaui fokus epistemologi Barat modern mulai abad 16-17 setelah Descartes, Locke dan Kant yang ketiganya lebih sibuk merumuskan syaratsyarat formal sebagai dasar pengetahuan yang sahih dalam mencerminkan realitas dan karena itu hanya menciptakan dunia teori-abstrak dan kontemplasi. Alih-alih kontemplasi, dalam arus yang berlawanan melalui pragmatisme yang dirumuskannya, Rorty menyuarakan keutamaan dimensi konkret hidup manusia yang menyatu dengan dimensi aksi. Dengan kata lain, mengetahui ciri-ciri pragmatisme dalam pemikiran Rorty sama halnya dengan memahami kritik perlawanannya terhadap epistemologi Barat modern yang dianggapnya berkutat di dunia teori. Guna memahami esensi pragmatisme Rorty, ada tiga bahasan utama yang akan dijelaskan: (1) pemikiran Rorty tentang karakteristik epistemologi Barat modern, (2) ciri-ciri pragmatisme dan (3) konsekuensinya terhadap fungsi filsafat dalam pandangan Rorty. Fungsi filsafat, dalam pragmatisme Rorty adalah sebagai sarana untuk mencapai tujuan hidup manusia. Pragmatisme Rorty mengafirmasi keberagaman nilai dan kepentingan manusia sebagai subjek konkret.

Kata kunci: pragmatisme, epistemologi, fondasi, representasi, dan konkret.

\section{Abstract}

This essay focuses on characteristic of pragmatism and its philosophical function in pragmatism milieu that has been improved by Richard Rorty. It dicussess Rorty's famous book: Philosophy and the Mirror of Nature. In 
Rorty's view, pragmatism is a new philosophy orientation that goes beyond modern Western epistemology tradition. Epistemology in Western tradition since the 16-17 Century have been deeply influenced by Descartes, Locke and Kant, who spent great effort in stipulating all formal a priori categories as foundational constitutive factors of human knowledge. Such fondational knowledge is believed to represent reality and creates abstract-apriori and contemplation world. Instead of contemplation, Rorty pragmatism suggests a reverse way of knowing by introducing to the virtue of human's concrete dimension which is united with dimension of action. In other words, understanding Rorty's characteristic of pragmatism the same way to understand his critics against modern Western epistemology which has only created an abstract world and contemplation. The paper offers three parts of discussions; firstly, Rorty's view on modern Western epistemology; followed by general characteristic of Rorty's pragmatism, and last, its consequence toward philosophy function. Through pragmatism, Rorty affirms his support to plurality of human values and interest as concrete subject.

Keywords: pragmatism, epistemology, foundation, representation and concrete.

\section{PENDAHULUAN}

Pragmatisme tumbuh subur pertama kali di Amerika Serikat yang dirintis oleh tiga tokoh utama Charles Sanders Peirce, William James dan John Dewey sejak abad ke-19. Mereka adalah bapak pendiri pragmatisme yang pemikirannya dapat diidentifikasi sebagai pragmatisme klasik dan menandai fase pertama perkembangan pragmatisme di Amerika (Margolis, 2006: 4). Fase kedua pragmatisme berikutnya diisi dengan pemikiran seperti Hillary Putnam dan salah satunya adalah Richard Rorty.

Pada tahun 1979, Rorty merilis untuk pertama kalinya buku filsafat yang ditulis olehnya dengan judul Filsafat dan Cermin Alam (Philosophy and the Mirror of Nature). Dengan buku itu, Rorty bermaksud ingin menegaskan kembali berakhirnya era metafisika dan epistemologi sebagaimana telah dirintis oleh Nietzsche dan Heidegger. Di Amerika sendiri penolakan terhadap kerangka filsafat demikian turut disuarakan oleh Dewey. Rorty bergabung ke dalam kubu penolakan itu. Sejak Descartes, fokus filsafat Barat modern adalah membangun sistem filsafat yang mampu memberikan orientasi beserta aturan-aturan normatif sebagai fondasi yang 
menjamin kepastian dan kebenaran pengetahuan manusia. Rorty memahami rintisan Descartes kepada filsafat Barat modern yang mengajarkan bahwa agar suatu klaim pengetahuan benar-benar memberikan kepastian, mesti berpijak kepada satu dasar yang kokoh, cukup diri, dan tak tergantikan, sudahlah usang. Filsafat Barat modern sejak Descartes yang terpusat kepada kajian tentang dasar atau syarat-syarat pengetahuan di mana filsafat semata-mata hanya bertujuan mengatasi problem pengetahuan sebenarnya telah menciptakan panorama filsafat yang sangat teoritis, reduktif dan kaku. Model filsafat semacam inilah yang ingin disingkirkan Rorty karena tidak lagi memadai di tengah dunia yang semakin dinamis dan dihuni oleh masyarakat yang juga semakin plural dengan pelbagai macam nilai-kepercayaan dan kepentingan yang dipeluknya.

Bertolak dari latar belakang tersebut, tulisan ini hendak menelusuri dan menerangkan pemikiran pragmatisme Rorty yang tidak dapat terpisahkan dari kritiknya terhadap epistemologi Barat. Pandangan kritis Rorty terhadap arus utama filsafat Barat modern yang terpusat kepada problem pengetahuan, adalah dasar bagi pengembangan filsafat praktis (etika) Rorty yang beraliran liberal dan turut menjadi ciri khas pemikiran pragmatis Rorty. Tulisan ini, namun demikian membatasi diri hanya kepada dua pertanyaan: (1) apakah ciri-ciri umum filsafat pragamatisme Rorty itu sendiri dan (2) apa konsekuensinya secara khusus kepada fungsi filsafat dalam cakrawala pragmatisme Rorty. Tulisan ini diawali dengan riwayat hidup dan karir Rorty serta relasinya dengan perkembangan pragmatisme di Amerika Serikat. Sesudahnya, penulis masuk ke dalam uraian Rorty tentang epistemologi Barat, ciri-ciri umum pragmatisme dan dampaknya kepada fungsi filsafat.

\section{RORTY DAN PRAGMATISME DI AMERIKA}

Richard Mckay Rorty lahir di New York, Amerika Serikat, 4 Oktober 1931 sebagai anak tunggal. Orang tuanya James dan Winifred Rorty dikenal sebagai pengagum dan pendukung gagasan sosialisme Leon Trotsky dan anti-Stalin (Tartaglia, 2007: 10). Bukubuku tentang pandangan Trotsky, terutama Kasus tentang Leon Trotsky (The Case for Leon Trotsky) dianggap memiliki kehormatan yang sama 
dengan Alkitab (The New York Times, 2007). Mereka berdua juga aktif menulis tentang wacana perubahan sosial di bawah pengaruh pandangan kiri. Tak heran, rumah Rorty turut menjadi basis pertemuan membahas gagasan-gagasan kiri, bahkan menjadi tempat persembunyian bagi pengikut setia Trotsky yang terpencar ke pelbagai negara termasuk di AS yang dianggap sebagai ancaman oleh rezim sosialis Stalin. Spirit ideologi kiri yang sangat meresapi keluarga Rorty, membentuk kesadaran Rorty yang saat itu baru berusia 12 tahun bahwa manusia mesti memiliki tujuan untuk melawan ketidakadilan (The New York Times, 2007).

Rorty remaja adalah korban bullying (perundungan) di sekolah karena di mata teman-temannya, ia adalah anak dengan pemikiran yang telah dewasa sebelum waktunya (precocius). Karena itu, sejak usia 15 tahun ia dipindahkan ke SMA Hutchins di kompleks Universitas Chicago, dan menempuh studi perguruan tinggi di tempat yang sama hingga ke jenjang Strata Dua. Sementara itu, pendidikan doktoralnya diambilnya di Universitas Yale. Rorty menulis tesis dan disertasi tentang filsuf Hegelian asal Amerika Serikat, Alfred North Whitehead (Tartaglia, 2007: 12) yang terpandang dengan gagasan filsafat proses. Karir Rorty sendiri diawali di Universitas Princeton selama kurun waktu 21 tahun (19611982) pada departemen ilmu-ilmu manusia hingga memperoleh kedudukan sebagai profesor filsafat. Kemudian tahun 1982-1998 menjabat sebagai profesor ilmu-ilmu manusia di Universitas Virginia. Dan sejak tahun 1998 hingga sebelum kematiannya pada tahun 2007, ia aktif mengajar sebagai profesor sastra komparatif di Universitas Stanford (Nielsen, 2006: 127).

Pada masa-masa awal karirnya di Universitas Princeton, Rorty mengampu mata kuliah filsafat analitis seperti terlihat pada pemikiran Rudolf Carnap atau Wittgenstein. Meski demikian, Rorty semakin tidak puas dengan metode filsafat analitis yang sekadar bertugas mengklasifikasi (taksonomi) berbagai macam cara berpikir dalam mendekati realitas, daripada berhadapan langsung (berkonfrontasi) dan membangun polemik secara dialektis terhadap suatu ide. Rorty pun kemudian mulai beralih mendalami pragmatisme (Tartaglia, 2007: 12). Sebagaimana telah disinggung di 
awal, pragmatisme tumbuh di Amerika Serikat dan dianggap sebagai pandangan filsafat yang secara orisinil dihasilkan dari benua Amerika (The New York Times, 2007) oleh para pendirinya seperti: CS Peirce, William James dan John Dewey. Namun, pragmatisme Rorty lebih dipengaruhi oleh James dan Dewey, sehingga hanya dua pemikiran tokoh itulah yang akan diterangkan berikut untuk melihat garis-garis besar pemikiran pragmatisme.

William James (1842-1910), sebagaimana diulas oleh Ellen K. Suckiel (2006), menegaskan secara eksplisit bahwa kepentingan dan tujuan subjek adalah salah satu elemen penting dalam filsafat pragmatisnya. Dalam konteks ini, James memahami prinsip objektivitas (realitas), kebenaran, dan realitas merupakan gagasan transendental yang sudah harus disingkirkan karena beroperasi di atas dasar syarat-syarat yang absolut, universal, abadi dan sama sekali tidak mengikuti dinamika partikularitas hidup manusia. (Suckiel, 2006: 32). Wawasan yang mengajark an bahwa kepentingan diri harus ditanggalkan dan cukup hanya berpijak kepada prosedur universal yang sudah ditentukan, misalnya bergantung kepada faktor rasio manusia seperti dicetuskan oleh Descartes atau bertumpu sepenuhnya hanya kepada dimensi pengalaman subjek oleh Locke sebagai basis mutlak pengetahuan dan kebenaran, dengan kata lain, ditolak oleh James sebab kepentingan individu sama sekali tidak menjadi acuan di dalamnya.

Di dalam kerangka transendental itu, kepentingan dan tujuan subjek, sebaliknya harus menjadi entitas netral dan independen (tidak dilibatkan dan tidak bergantung) demi kepastian kebenaran yang berderajat tinggi (Suckiel, 2006: 32). Ini artinya, pengertian kebenaran, objektivitas dan realitas yang dikembangkan di atas dasar prinsip universal dan transendental telah mendorong kebenaran atau pengetahuan harus bersifat objektif, yaitu di satu sisi, mesti bebas dari segala dimensi subjek (kepentingan, hasrat dan kebutuhannya), tetapi di sisi lain, pengetahuan subjek harus merepresentasikan realitas di luar dirinya seakurat mungkin sebagai tolok ukur derajat kebenaran pengetahuan. Semakin pengetahuan itu mampu mengungkapkan kembali realitas pengamatannya sesuai dengan kenyataan secara akurat, semakin kebenaran di dalamnya dapat dipercayai. Inilah yang 
dipahami di dalam teori kebenaran korespondensi bahwa kebenaran dinilai hanya didasarkan kepada kesesuaian proposisi klaim pengetahuan dengan realitas.

Namun, James benar-benar menolak teori kebenaran korespondensi tradisional itu (Suckiel, 2006: 36). Ia menolak kebenaran berasaskan transendental objektif dan korespondensi representatif karena telah melampaui pengalaman subjek dan karena itu kebenaran menjadi tidak masuk akal (Suckiel, 2006: 37). Dimensi subjek yang dikeluarkan dari orbit kebenaran demi kepastian murni sebagaimana kenyataan yang ada dan subjek dituntut hanya taat kepada norma yang telah ditetapkan seperti oleh Descartes dan Locke, misalnya, sama sekali tidak dapat diterima. Bagi James, tidak ada pandangan yang bisa dibenarkan jika mengasingkan diri dari dimensi kepentingan individu.

Sebagaimana dicatat oleh Suckiel, kebenaran menurut James mesti dipahami di dalam kerangka pragmatis. Suatu kepercayaan/ajaran dinilai sebagai kebenaran sejauh dapat memuaskan tujuan dan kepentingan pemeluknya (Suckiel, 2006: 37). Dalam analisis Bertrand Russell, bagi James sebuah gagasan adalah benar sejauh dapat memberikan kepuasan dalam diri kita, yakni sejauh menguntungkan (profitable) kehidupan kita (Russell, 1972: 816). Dengan kata lain, pragmatisme James mengajarkan kita untuk memeriksa efek dari suatu ajaran kebenaran/kepercayaan. Sejauh kepercayaan itu menguntungkan dan mampu memuaskan kepentingan seseorang, sejauh itu pula ia layak dianut sebagai kebenaran. Dan filsafat berfungsi menemukan efek dari suatu klaim yang dianggap benar. Teori/filsafat dalam hal ini mulai dimengerti sebagai suatu instrumen (Russell, 1972: 816) yang bermanfaat secara praktis.

Yang menarik untuk diketahui, Philip W. Jackson dalam tulisannya memberitahukan pada kita bahwa James tidak merasa nyaman untuk menamai pemikirannya dengan pragmatisme karena terlanjur memiliki banyak salah pengertian di masyarakat. Fokus pemikiran James sebenarnya terletak pada kajiannya terhadap sifat pragmatis yang mungkin terkandung dalam suatu ajaran kebenaran/pengetahuan (Jackson, 2006: 59). John Dewey sependapat 
dengan James. Ia merasa tidak mantap menggunakan istilah pragmatisme. Yang ingin didalami adalah sifat pragmatis, yang secara hakiki masih meneruskan prinsip efek dalam pandangan James. Menurut Dewey, “...tafsiran yang memadai terhadap sifat pragmatis, terletak pada fungsi konsekuensi sebagai titik uji yang penting terhadap validitas suatu proposisi" (dikutip dari Jackson, 2006: 59). "istilah pragmatis", bagi Dewey, "mengacu kepada segala bentuk pemikiran, segala pertimbangan reflektif hanya kepada konsekuensi sebagai makna dan pengujian final" (dikutip dari Jackson, 2006: 60). Menguji sifat pragmatis adalah dengan menyelidiki kemungkinan konsekuensi suatu proposisi atau ajaran kebenaran. Bersikap pragmatis secara implisit turut merangsang nalar seseorang untuk menyelidiki dan mempertimbangkan pelbagai kemungkinan konsekuensi. Bersikap pragmatis turut merepresentasikan suatu rasionalitas tertentu, yakni mempertimbangkan kemungkinan efek/konsekuensi yang mungkin terjadi.

Meminjam analisis Jackson, pragmatisme Dewey (dapat dikatakan demikian tanpa mengurangi dasar-dasar pemikiran Dewey) yang mendorong olah nalar seseorang untuk mempertimbangkan konsekuensi atas pilihan perbuatannya, janganlah dipahami hanya perkara mengumpulkan data-data akibat, melainkan lebih mendasar dari itu bahwa bersikap pragmatis menyiratkan pendayagunaan nalar seseorang demi kemajuan hidupnya (Jackson, 2006: 60). Dan dengan mempertimbangkan kemungkinan efek, rasio memiliki peran mendasar dalam mengendalikan masa depan. Menerangkan gagasan Dewey, Russell menjelaskan bahwa menurut Dewey kebenaran hanya dapat diperoleh sejauh ada faktor yang menjamin (warranted assertability), dan faktor itu terletak pada konsekuensi (efek) yang dapat mengembangkan hidupnya lebih baik.

Artinya, konsekuensi memuat dimensi masa depan. Jika kebenaran bertumpu kepada faktor efek, maka kebenaran jelas berorientasi kepada masa depan dan di tangan subjek sajalah, kualitas masa depan dapat ditentukan (Russell, 2006: 826). Dapat dikatakan, dengan menitikberatkan pada faktor konsekuensi, pragmatisme Dewey setidaknya memuat dua unsur penting: unsur rasionalitas 
dan unsur masa depan. Pada unsur pertama, pragmatisme Dewey memancarkan 'paras' idealisme atas peran rasio subjek, tidak untuk kepentingan teoritis-abstrak, melainkan untuk tujuan hidup yang aktual-konkret (Jackson, 2006: 60). Dan dengan dimensi masa depan yang hanya dapat dikendalikan oleh subjek, Dewey seolah menegaskan keberpihakan dan pengakuannya terhadap kebebasan dan kekuatan subjek dalam menentukan arah masa depannya (Russell, 1972: 826). Pragmatisme Dewey tidak saja idealis, tetapi juga berorientasi humanis (Jackson, 2006: 60).

Pemikiran para pendiri pragmatisme di Amerika: James dan Dewey, yang berpihak dan berorientasi kepada dimensi subjek konkret dan faktor praktis kepentingannya membentuk alam pikir pragmatisme Rorty. Namun, untuk membedah pokok-pokok pragmatisme Rorty, kita tidak dapat menggunakan jalan langsung. Pragmatisme Rorty tidak dapat dipisahkan dari usaha penemuannya terhadap ciri-ciri khas epistemologi Barat karena inilah yang menjadi dasar Rorty membangun pragmatismenya. Maka dari itu, pengertian Rorty terhadap epistemologi Barat terlebih dahulu harus diuraikan.

\section{EPISTEMOLOGI BARAT MODERN MENURUT RORTY}

Dalam Philosophy and Mirror of Nature (selanjutnya PMN), pemikiran-pemikiran Descartes dan Hobbes yang disebut Rorty menandai "permulaan filsafat modern", sebenarnya memuat suatu semangat dukungan terhadap merekahnya ilmu pengetahuan (sains: matematika dan mekanika) yang dimulai dari kehadiran gagasan revolusioner Copernicus dan Galileo. Dukungan ini juga dapat diartikan sebagai perjuangan pembebasan daya intelektual masyarakat dari dominasi kekuasaan gereja (baca: Gereja Katolik) (PMN 131). Bahwa gereja melalui doktrin-doktrinnya menguasai dan mendikte cara berpikir, penghayatan dan perilaku masyarakat di Eropa, bahkan merangsek hingga ke dalam wilayah ilmu pengetahuan, menentukan apa yang dianggap sah sebagai ilmu pengetahuan. Dalam kondisi ini belum ada kesadaran untuk memisahkan filsafat dengan sains. Namun, seiring dengan perlawanan terhadap hegemoni gereja yang justru semakin menyuburkan penemuan-penemuan sains, kebutuhan pemisahan itu 
semakin menguat karena perbedaan orientasi di antara filsafat dengan sains yang semakin terang-benderang.

Pencapaian sains dengan temuan-temuannya yang monumental kiranya menjadi suatu latar belakang yang tak dapat disangkal bagi filsafat untuk menemukan fokus penyelidikannya. Dan Rorty melihat fokus filsafat sejak masa itu tertuju kepada problem pengetahuan; filsafat yang hendak memosisikan diri sebagai "teori pengetahuan" (PMN 132). Artinya, fokus filsafat adalah epistemologi. Dari akar bahasa Yunani, epistemologi terbentuk dari kata: episteme yang berarti pengetahuan, dan logos berarti: pikiran, perkataan atau pengetahuan. Secara ringkas, epistemologi adalah cabang filsafat yang fokus menemukan dan mengkaji dasar-dasar teoritis, ciri-ciri umum dan hakikat pengetahuan (Sudarminta, 2002: 18). Dan Rorty mengidentifikasi bahwa epistemologi telah menjadi orientasi filsafat Barat modern. Dalam kaitannya dengan hal itu, ada tiga aspek utama tentang epistemologi Barat yang diuraikan oleh Rorty.

\section{Tentang Fondasi Pengetahuan}

Berbeda dengan sains yang berorientasi menyingkapkan realitas dan berwujud ke pelbagai bidang sains, fokus filsafat jauh lebih mendasar dan mendahului dari semangat sains untuk melahirkan pengetahuan. Menurut Rorty, dengan meminjam ungkapan dari Kant, filsafat justru hendak menyelidiki, "bagaimana suatu pengetahuan dimungkinkan?" (PMN 132). Jika sains bertanya apa yang dapat ditemukan dari suatu realitas sehingga dapat menyediakan suatu pengetahuaan baru, bagi filsafat yang pokok adalah bagaimana sesuatu dapat mungkin dan sahih disebut sebagai pengetahuan. Karena itu bagi Rorty, perbedaan fungsi filsafat sebagai "teori pengetahuan" dengan sains ialah terutama karena filsafat mencari suatu "fondasi"/dasar (foundation) yang memungkinkan berdirinya suatu pengetahuan (PMN 132). Fokus epistemologi adalah menemukan dasar yang kokoh, jelas dengan sendirinya, tak dapat salah dan dikoreksi bagi berdirinya pengetahuan manusia (Sudarminta, 2002: 138-139). Meminjam pandangan Dewey, dasar inilah yang menjadi "jaminan kebenaran" (warranted assertability) pengetahuan sebagai fokus filsafat yang tak dapat ditemukan dalam 
aktivitas sains yang menurut Rorty faktor ini juga menjadi "pembeda" dan "pemisah" antara filsafat dan sains (PMN 131-132).

Rorty mencatat tiga tokoh: Descartes, John Locke, dan Immanuel Kant sebagai tokoh-tokoh yang berkonsentrasi menyediakan fondasi pengetahuan. Bagi Descartes, basis pengetahuan adalah pikiran (rasio). Pengetahuan hanya dapat dihasilkan dari subjek "aku yang berpikir". Di luar dari faktor rasio, klaim kebenaran pengetahuan sudah semestinya ditolak. Lalu muncul Locke dengan gagasannya yang baru, yang meyakini pengalaman (empiris) dan penginderaan, alih-alih rasio, sebagai satu-satunya sumber (fondasi) pengetahuan. Keterlibatan manusia di dalam dunia menghasilkan suatu pengalaman sendiri yang pada gilirannya membentuk pengetahuan seseorang. Pemikiran kedua filsuf ini, diakui Rorty memberikan sumbangan bagi tersedianya "kepastian" (PMN 137) sebagai tujuan yang ingin dicapai oleh suatu pengetahuan/ajaran kebenaran. Descartes dan Locke menyediakan aturan yang diklaim menjamin kepastian pengetahuan manusia, sejauh suatu klaim kebenaran bersumber dari salah satu aturan tersebut, maka kebenarannya dapat diterima.

Meski demikian, pengakuan Rorty lebih ditujukan kepada Kant. Rorty melihat Kant menjawab problem fondasi pengetahuan dengan melakukan sintesis rasionalisme Descartes dan empirisme Locke, yaitu: sintesis dimensi "formal" (konseptual) dan "material" (intuisi penginderaan) (PMN 138). Sintesis ini termanifestasi ke dalam suatu struktur formal apriori sebagai basis yang mengkonstitusi pengetahuan manusia, yang terdiri atas dua bagian: pada taraf inderawi ditentukan di dalam kategori ruang dan waktu, dan pada taraf akal budi diatur di dalam 12 kategori yang sudah terpetakan di dalam pikiran manusia (bdk. Sudarminta, 2002: 29). Struktur formal yang dibangun oleh Kant secara apriori (mendahului pengalaman) adalah jawaban Kant atas teka-teki problem basis pengetahuan yang berfungsi mengatur aktivitas berpengetahuan manusia dan tentu saja bobot kebenaran di dalamnya. Kant telah menghasilkan prosedur pengetahuan yang transendental (melampaui temporalitas dunia; tidak terikat ruang dan waktu) dan universal sebagai prinsip epistemologi, dan dasar bagi pengembangan filsafat moral Kant. 
Gagasan epistemologi Kant yang fundamental dan komprehensif menciptakan bangunan pemikiran yang sedemikian kokoh dan komplit. Karena itulah menurut Rorty, sejak Kant filsafat sebagai epistemologi menjadi lebih "sadar diri" (self-conscious) dan penuh "percaya diri" (self-confident) (PMN 138) akan tugasnya mengatasi problem pengetahuan. Gagasan Kant, menurut Rorty, telah menciptakan suatu "versi standar sejarah filsafat modern" (PMN 148). Dan berdasar kepada Kant, definisi epistemologi memiliki bentuk yang lebih tajam, yakni menyelidiki dimensi formal atau struktur yang mendasari kepercayaan atau pengetahuan kita (PMN 162).

Dengan demikian, tema fondasi pengetahuan sebagai fokus epistemologi filsafat Barat modern, bagi Rorty, sebenarnya merupakan penyelidikan filosofis terhadap faktor penyebab (cause) pengetahuan. Pada Descartes tertuju kepada pikiran (rasio) subjek, pada Locke mengacu kepada pengalaman dan penginderaan, sementara dalam Kant, penyebab yang mendasari pengetahuan manusia adalah struktur apriori pada tingkat inderawi ataupun akal budi (PMN 159). Faktor penyebab adalah basis terpercaya yang memastikan bobot kebenaran kepercayaan atau pengetahuan kita terhadap objek yang diketahui.

Namun, penyebab (fondasi) pengetahuan adalah satu hal sendiri. Pengetahuan dalam epistemologi Barat modern tidak cukup berhenti hanya pada persoalan pendasaran, melainkan dari basis yang kokoh, jelas dengan sendirinya, cukup diri, dan tak dapat salah sebagai suatu kerangka pengetahuan yang kuat, pengetahuan mampu menyediakan wawasan sesuai dengan realitas yang ada. Suatu pengetahuan yang tidak melampaui batas realitas dunia manusia (immanensi), tetapi pengetahuan yang menampilkan realitas dunia dengan sebenar-benarnya: realitas yang objektif. Dalam hal ini, Rorty melihat bahwa pengetahuan berfungsi untuk merepresentasikan realitas.

\section{Fungsi Representasi Pengetahuan}

Mengetahui, menurut Rorty adalah "merepresentasikan secara akurat realitas di luar pikiran; maka, untuk memahami hakikat dan batas kemungkinan pengetahuan berarti memahami cara pikiran 
subjek untuk mampu membangun suatu representasi" terhadap realitas (PMN 3). Dan bagi Rorty, pihak yang berdaya merepresentasikan realitas adalah pikiran subjek (mind) (PMN 3). Pikiran memiliki kemampuan untuk merekam dan menyajikan kembali realitas di luar dirinya secara akurat, dan pengetahuan adalah produk representasi pikiran subjek. Pengetahuan dalam ilmu alam atau sosial, misalnya, dapat dikatakan suatu manifestasi representasi pikiran subjek terhadap objek realitas di luar dirinya. Daya representasi pikiran terhadap realitas, bagi Rorty dengan menggunakan suatu metafor, memperlihatkan kemampuan pikiran untuk mencerminkan realitas.

Pikiran adalah cermin yang dapat memantulkan kembali kenyataan di luar dirinya. "Pikiran sebagai sebuah cermin yang mengandung pelbagai macam bentuk representasi-beberapa ada yang akurat, beberapa ada yang tidak-yang dapat dikaji oleh metode murni nonempiris" (PMN 12). Gagasan rasionalisme murni oleh Descartes bahwa hanya pikiran (rasio) subjek sajalah yang mampu memberikan kepastian pengetahuan, atau empirisme Locke bahwa sumber pengetahuan adalah pengalaman dari proses penginderaan subjek, dan kemudian disintesiskan oleh Kant menghasilkan prosedur apriori pengetahuan, menurut Rorty merupakan upaya para filsuf untuk menyediakan bentuk-bentuk representasi/jenis-jenis cermin yang dapat mencerminkan realitas secara akurat dan karenanya pula memungkinkan terbentuknya pengetahuan manusia secara akurat. Epistemologi Kant, bagi Rorty, adalah penyelidikan problem pengetahuan yang mengerucut kepada relasi dua bentuk "representasi" yang berbeda: bentuk formal/konsep (apriori), dan bentuk material/intuisi (aposteriori) (PMN 138 \& 148) sebagai syarat transendental pengetahuan. Dan bentuk-bentuk representasi yang terejawantah ke dalam prinsip-prinsip epistemologi tertentu sebagaimana dalam Descartes, Locke atau Kant, bagaimanapun juga adalah produk apriori yang dihasilkan melalui proses pengkajian secara rasional murni.

Bagi Rorty, kedudukan pengetahuan sebagai representasi realitas adalah warisan pemikiran abad ke 17 (PMN 136). Oleh Descartes, Locke, dan Kant-filsuf abad ke 17-pikiran subjek 
dianggap mampu merepresentasikan realitas, dan karena itu pula mampu menghasilkan pengetahuan bagi dirinya. Mereka menerjemahkan dan mengartikulasikan daya representasi pikiran ke dalam konsep-konsep epistemologi mereka masing-masing, seperti: ke dalam rasio, pengalaman atau sintesis keduanya, yang diklaim mampu menyediakan bentuk representasi realitas (pengetahuan) yang paling akurat. Dan oleh karena sumber pengetahuan bertumpu kepada daya representasi subjek, maka pengetahuan itu sendiri sebenarnya mencerminkan daya instrinsik subjek (inner representation) (PMN 149), yakni pikiran subjek yang memiliki kapabilitas untuk menyajikan kembali realitas sebagaimana adanya. Bahkan daya instrinsik subjek (pikiran) yang ditempatkan secara absolut oleh para filsuf epistemologi abad 17, dimengerti Rorty sebagai bentuk representasi yang sangat istimewa ("privileged representations") (PMN 163) karena memiliki akses untuk mengetahui realitas sebagaimana adanya yang tak dapat salah ("to know itself incorrigibly") (PMN 35).

Oleh karena itu, sebagaimana ditulis oleh James Tartaglia, pikiran adalah faktor yang dimaksud Rorty yang memiliki fungsi secara fundamental sebagai cermin untuk merepresentasikan realitas. Dan dalam hubungannya dengan fokus kajian epistemologi Barat modern tentang pengetahuan yang legitimate (sahih), dimensi pikiran subjek juga sama sekali tidak dapat dipisahkan di dalamnya. Tartaglia mengatakan,

"[...] ketika kita mulai menetapkan fungsi pikiran untuk merepresentasikan realitas, maka fokus epistemologi atau teori pengetahuan menjadi sangat jelas; pikiran menjadi satu-satunya titik epistemik dalam hubungan kontak manusia dengan dunia sejak dipahaminya segala pengetahuan lahir dari pengalaman dan pikiran, dan (bagaimanapun juga) keduanya adalah bentuk pikiran. Dengan mencoba memahami pikiran, maka, para filsuf mulai berupaya untuk memastikan syarat-syarat yang mampu merepresentasikan realitas dengan benar, dan karena itu pula, kondisi umum yang darinya pengetahuan dapat dimungkinkan. Sebuah teori yang dapat memberitahukan pada kita metode penelitian mana yang yang dapat dipercaya, dan karenanya dapat 
memungkinkan kita untuk mempertahankan suatu klaim tertentu tentang dunia" (Tartaglia, 2007: 28).

Dengan kata lain, secara keseluruhan, fokus epistemologi Barat adalah menyediakan teori pengetahuan yang sama sekali berbeda dengan sains; terpusat kepada upaya untuk meletakkan fondasi pengetahuan sebagai jaminan legitimasi pengetahuan yang benar ke dalam pelbagai macam bentuk konsep-konsep representasi pikiran (seperti dalam Descartes, Locke dan Kant), bahwa benar sejauh dapat mengungkapkan kembali realitas secara akurat tepat. Dan pikiran adalah faktor intrinsik subjek yang ditunjuk oleh para filsuf Barat abad 17 sebagai fondasi (sumber) pengetahuan yang kokoh, cukup diri dan tak dapat salah, dan sekaligus berdaya kuat dalam merepresentasikan realitas. Filsafat Barat menemukan obsesinya menjadi teori pengetahuan (epistemologi). Dalam hal ini, filsafat di mata Rorty menjadi sebuah teori representasi umum yang mendalami pelbagai bentuk konsepsi representasi pikiran untuk menyediakan panduan dalam menentukan pengetahuan mana yang memiliki bobot representasi realitas yang kuat dan mana yang tidak (PMN 3).

Jika pengalaman empiris ala Locke adalah basis pengetahuan yang sahih, maka aktivitas sains dipandang memiliki kemampuan yang paling tinggi dalam merepresentasikan realitas. Sains dipandang sebagai bentuk pengetahuan yang paling kredibel, di mana di dalamnya penyelidikan di ruang astronomi berada di urutan terakhir, sementara psikoanalisis ala Freud sebagai metode psikologi berada di urutan tengah. Lantas jika basis pengetahuan secara mendasar terletak pada aktivitas penalaran (refleksi) subjek, maka filsafatlah yang memiliki daya representasi yang paling kuat (Tartaglia, 2007: 17) karena menghasilkan wawasan dunia secara mendasar dan menyeluruh (metafisis) yang dapat berlaku secara universal. Dengan 'anatomi' semacam ini, filsafat bagi Rorty sekaligus berperan sebagai "pengawas budaya" (Tartaglia, 2007: 16).

\section{Teori Kebenaran Korespondensi}

Fungsi pengetahuan merepresentasikan (menghadirkan kembali) realitas dunia seakurat mungkin, pada gilirannya tidak 
terpisahkan dengan teori kebenaran korespondensi (PMN 334). Teori kebenaran ini mengajarkan bahwa suatu proposisi (pernyataan) yang mengekspresikan suatu objek tertentu dapat dinyatakan benar apabila sesuai (berkorespondensi) dengan objek yang bersangkutan. Sesuatu dinilai benar sejauh dapat ditunjuk kepada objek yang ada pada kenyataan atau memiliki kesamaan struktur di antara keduanya (Sudarminta, 2002; 130). Esensi kebenaran, oleh karena itu, ditentukan secara realis, yakni benar-benar sesuai dengan kenyataan yang ada, yang berasal dari dirinya sendiri dan tidak bergantung kepada hal-hal eksternal. Maka, Rorty di dalam karyanya Philosophy and Social Hope (selanjutnya PSH), memahami kebenaran dapat tersingkapkan karena ditemukan (found). Fungsi pengetahuan adalah untuk menemukan realitas di luar diri subjek, merekam dan mengungkapkannya kembali seakurat mungkin. Hanya dengan mekanisme representatif dan realis inilah, yakni dengan menemukan dan melaporkan realitas sebagaimana adanya, kebenaran sejati dapat diperoleh.

\section{CIRI-CIRI PRAGMATISME RORTY}

Apa yang diuraikan Rorty atas pandangannya terhadap epistemologi Barat modern, seolah-olah memperlihatkan afirmasinya terhadap tugas penyelidikan filsafat dalam mengkaji struktur pengetahuan manusia dan meletakkan aturan-aturan sekaligus batasan pengetahuan yang sahih. Namun, pragmatisme Rorty tidaklah demikian. Dengan menelusuri proyek epistemologi Barat modern, Rorty semakin menemukan tujuan moral di dalamnya, yakni filsafat Barat yang berupaya membangun suatu budaya kebenaran yang kokoh dan abadi, kebenaran yang hanya dapat diperoleh dari suatu landasan niscaya, yakni daya intrinsik subjek, dan ditetapkan sebagai asas teoritis tunggal sebagai dasar perkembangan pengetahuan yang benar. Rorty sepenuhnya menolak spirit ini. Penolakannya terhadap tradisi epistemologi Barat menjadi dasar pengembangan pragmatismenya. Dalam tulisannya Pragmatism, Relativism and Irrationalism pada tahun 1980 (selanjutnya disingkat PRI), Rorty menuliskan empat ciri utama untuk menandai pragmatismenya. 


\section{Anti-esensialisme}

Apa yang dibangun oleh Descartes, Locke dan Kant dalam menyediakan fondasi pengetahuan dan berfungsi merepresentasikan realitas secara akurat, sebagaimana telah diulas di atas, dipandang Rorty sebagai strategi untuk menjamin legitimasi kebenaran pengetahuan manusia; kebenaran yang tidak mengecoh, melainkan sesuai dengan kenyataan yang ada. Usaha para filsuf abad ke 17 dengan meletakkan prosedur/prinsip sebagai fondasi pengetahuan, dapat diartikan sebagai langkah untuk memastikan kebenaran yang terkandung dalam pengetahuan. Epistemologi Barat modern semakin terobsesi terhadap kebenaran tunggal, absolut dan abadi. Filsafat sebagai teori pengetahuan (epistemologi) berhasrat menemukan esensi. Persis di titik ini, Rorty menentang etos epistemologi Barat yang mengejar esensi, yang berambisi memperoleh "kebenaran" (Tartaglia, 2007: 204). Terhadap penolakannya itu, Rorty mengatakan, "Ciri pertama yang ingin saya kemukakan dalam pragmatisme bahwa ia adalah paham yang anti-esensialisme terhadap konsepsi-konsepsi seperti 'kebenaran', 'pengetahuan', 'bahasa' 'moralitas' dan segala konsepsi yang serupa sebagai objek teoritisasi filsafat" (PRI 295). Karena bagi Rorty dengan mengikuti William James, kebenaran bukan perihal esensi (PRI 295); esensi yang diperoleh karena kita memasuki arena teori. Secara spesifik, spirit esensialisme yang ditolak Rorty adalah teori kebenaran korespondensi (PRI 295).

Rorty menolak segala bentuk motivasi yang ingin memuaskan dahaga akan kebenaran: kebenaran yang semata-mata bersesuaian secara akurat dengan realitas, yang bagaimana pun juga, merupakan kebenaran di ranah teoritis. Kebenaran yang dihasilkan dari pengetahuan yang mampu merepresentasikan realitas secara akurat sebagaimana diajarkan dalam teori kebenaran korespondensi. Ini artinya, anti-esensialisme Rorty turut berbobot antirepresentasionisme. Dengan dasar ini, Rorty melihat hidup yang hanya dihabiskan untuk mencerminkan realitas dengan tepat, menjadi hidup yang hanya diisi dengan aktivitas merekam hasil-hasil pengamatan/perhitungan dan penalaran, membuka kembali datadata pengamatan sebagai cara untuk mendapatkan kebenaran (PRI 297). 
Oleh karena itu, Rorty menegaskan pertanyaan utama bagi kaum pragmatis, sebagaimana dikutip dari Dewey, "bukan tentang 'apakah sesuatu itu benar?'” sebagai objek pencarian para epistemolog Barat sejak abad 17 dalam menjamin kepastian dan kebenaran pengetahuan, melainkan "'apa konsekuensinya (bagiku) dari memercayai sesuatu?', 'apa yang akan terjadi jika saya menyakini ajaran tertentu?'” (PRI 296). Rorty ingin mengajak manusia, dengan kata lain, kepada pertanyaan inti kaum pragmatis tentang: manfaat apa yang akan diperoleh dari kepercayaan yang dipegang (PSH xxiv). Dengan mengikuti prinsip konsekuensi James atau Dewey, pertanyaan itu dapat dirumuskan: konsekuensi apa yang mungkin terjadi dari ajaran yang diyakini benar? Pertanyaan semacam inilah bagi kelompok pragmatis seperti Rorty yang semestinya menjadi orientasi para filsuf. Berangkat dari hal itu, Rorty menganjurkan untuk tidak pusing memikirkan apakah nilai kepercayaan yang dipegang benar-benar mencerminkan realitas baik secara fisik maupun psikis/mental atau tidak, melainkan fokus mempertimbangkan apakah kepercayaan tersebut merupakan suatu sarana terbaik untuk memuaskan hasrat (PSH xxiv).

Fokus menyelidiki bobot representasi realitas dalam pengetahuan atau kepercayaan, selain hanya merupakan suatu kajian teoritis, bagi Rorty dan kaum pragmatis toh hanya buang waktu dan pikiran saja! (PSH xxiv). Seperti dalam kajian filsafat bahasa yang diresapi oleh paham kebenaran korespondensi yang memastikan kondisi isomorfi suatu pernyataan (hubungan satu satu: bahwa suatu pernyataan benar-benar mengacu kepada objek yang satu dan spesifik), Rorty mengingatkan dengan mengikuti alur pikir James, kajian teoritis semacam itu tidak memberi pencerahan apapun terhadap keingintahuan manusia yang mendasar: mengapa suatu kebenaran tertentu sebaiknya dipercayai (PRI 295) atau mengapa mesti menempatkan suatu ajaran sebagai nilai yang harus konsisten dipegang.

Menurut Rorty, mereka yang menginginkan sebuah esensi akan menghendaki segala bentuk pengetahuan untuk selalu memuat kebenaran (esensi), tidak hanya untuk mengoreksi pandangan yang mereka anggap salah, tetapi sekaligus menjadi dasar untuk 
penemuan kebenaran selanjutnya (PRI 295), yang bagaimana pun masih di dalam dunia teori. Dengan ungkapan lain, pragmatisme Rorty berbobot anti-esensialisme sebagai penolakannya terhadap kebenaran yang ingin dicapai oleh kajian-kajian teoritis, secara mendasar karena Rorty menganggap pusat kehidupan tidak terletak pada perkara pencarian kebenaran, melainkan kepada strategi yang dapat memajukan kehidupan dan memenuhi kepentingan kita.

\section{Anti-epistemologi}

Berdasar kepada penolakannya terhadap tujuan kaum esensialis seperti Descartes, Locke dan Kant, Rorty melanjutkan pencirian filsafat pragmatismenya dengan menolak proyek epistemologi baik yang bertujuan menemukan kebenaran dalam level apapun maupun pelbagai perbedaan metodologi dalam mengungkapkan realitas (PRI 296).

Menurut Rorty, filsafat sebagai epistemologi merupakan pencarian struktur yang tetap sebagai fondasi yang mendasari pengetahuan, budaya dan kehidupan; suatu struktur yang diletakkan secara apriori oleh pikiran subjek atas dayanya yang istimewa dalam merepresentasikan realitas (PMN 163).

Struktur formal itu adalah prosedur normatif/aturan-aturan sebagai syarat membentuk pengetahuan dan menjamin kebenaran. Hanya dengan taat kepada prosedur normatif seperti yang sudah diletakkan oleh Descartes, Locke, dan Kant, menurut Rorty dalam pemahaman epistemologi Barat modern, manusia akan sampai kepada kebenaran yang sejati (PRI 296). Kendati dengan demikian, dalam pengertian Dewey (PRI 297), subjek sebenarnya sekadar sebagai penonton terhadap konsep-konsep abstrak pengetahuan ("the spectator theory of knowledge") yang mesti "patuh" (PRI 296) terhadapnya sebagai jalan abadi menuju kebenaran.

Filsafat sebagai epistemologi tidak terbatas kepada perihal fondasi pengetahuan yang mampu mencerminkan realitas dengan tepat, tetapi turut mencakup sifat abadi yang telah disematkan di dalamnya. Aturan/prinsip yang dibuat dalam menjamin kebenaran pengetahuan, tidak lekang oleh waktu; ia adalah suatu formula yang berstruktur tetap dan ahistoris. Maka, taat kepada aturan-aturan 
epistemologi berarti taat kepada batasan; taat kepada apa yang disebut Rorty sebagai "batasan abadi" (PMN 9) dalam lanskap filsafat pengetahuan Barat. Kajian epistemologi Barat terhadap penyelidikan prosedur/syarat pengetahuan yang tetap sepanjang zaman, dipandang Rorty sebagai aktivitas yang mendalami "problemproblem keabadian" (PMN 3; Tartaglia, 2007: 3), yang sebenarnya merupakan "persoalan yang palsu" (pseudo problems) (PMN 240; Kielsen, 2006: 129).

Dalam arah yang berlawanan, justru karena itu, Rorty menolak epistemologi. Rorty menolak prosedur normatif dan mekanisme ketaatan terhadap aturan yang sudah ditentukan sebagai 'cara main' dalam epistemologi Barat sejak abad ke 17 yang dipandang dapat menjamin kebenaran pengetahuan dengan mematuhi batasan normatif epistemologi. Penolakan Rorty terhadap epistemologi Barat dapat dianggap sebagai suatu pandangan yang anti-metode, yakni antipati terhadap pelbagai asas atau aturan yang mesti ditaati sebagai jaminan kebenaran dan bersifat abadi. Hal ini karena arus epistemologi, bagaimanapun, tetap bermuara kepada tercapainya kebenaran yang masih berwatak teoritis.

Penolakan Rorty terhadap epistemologi berarti bahwa Rorty tidak hanya menentang norma-norma yang perlu dipatuhi dalam memperoleh kebenaran, tetapi juga menyingkirkan dimensi teori dalam filsafatnya. Bagi Rorty kosakata-kosakata praktis lebih utama daripada kosakata teoritis, aksi lebih mendasar daripada kontemplasi; dan berdasar kepada keutamaan praktis, tuntutan kebenaran telah menemukan basis justifikasinya dalam khazanah pemikiran pragmatis (PRI 295). Rorty mendesak untuk mengganti dimensi teori (theoria) dengan dimensi perbuatan (phronesis) (PRI 296). Dalam pengertian praktis ini, tokoh-tokoh seperti Pasteur yang berdedikasi penuh terhadap upaya mengatasi penyakit, atau bahkan Marx yang fokus 'membakar' semangat transformasi sosial melalui praksis revolusioner kelas buruh, mendapatkan apresiasi yang sangat besar di mata pragmatisme Rorty (PRI 296).

Sudah jelas bahwa orientasi kaum pragmatis tidak terarah kepada dimensi teoritis, yakni mengkaji secara apriori (rasional murni) syarat formal pengetahuan manusia demi menjamin 
kebenaran sebagai proses penyelidikan teoritis. Sebaliknya, orientasi kaum pragmatis tertuju kepada pemuasan kepentingan dan kebutuhan hidup sebagai dimensi konkret hidup manusia. Dimensi praktis bagi pragmatisme Rorty terutama adalah upaya memajukan kehidupan manusia dan memuaskan kepentingannya. Dalam konteks itu, Rorty tidak membuat pemisahan antara teori dan praksis sebab sejauh teori dapat berfungsi secara praktis memadai meningkatkan kualitas hidup manusia dan dapat memenuhi kebutuhan hidupnya, sejauh itu pula dimensi teori diterima Rorty. Oleh karena tidak diterima sebagai orientasi di kalangan pragmatis, fokus menaati aturan demi kebenaran objektif sebagai tuntutan teoritis, sebagaimana ditegaskan oleh Rorty, sama sekali "tidaklah berguna" (PRI 297). Dalam pragmatisme Rorty, teori adalah sejauh di dalam batasan praktis (PSH xxv).

Namun, penolakan Rorty terhadap epistemologi Barat modern yang fokus terhadap fondasi dan fungsi representasi pengetahuan, tidak berarti dengan kritiknya, Rorty ingin menghapus wawasan epistemologi Barat sejak abad 17 sebagai bagian dari sejarah filsafat Barat. Sebaliknya Rorty mengakui bahwa wawasan epistemologi sejak era itu telah menyediakan tangga yang bermanfaat bagi para filsuf mengatasi problem filsafat di zaman itu. Kendati demikian, menurut Rorty manusia perlu menendang tangga itu. Bukan karena manusia tidak lagi memiliki persoalan dan tantangan filosofis, melainkan karena manusia memiliki bentuk persoalan yang berbeda dari kondisi sebelumnya, dan tangga itu (yaitu: epistemologi sebagai filsafat pengetahuan yang memiliki pelbagai prosedur dan prinsip tetap) tidak diperlukan lagi karena tidak relevan dengan situasi kontemporer (PSH xxii) yang lebih memerlukan pendekatan secara praktis-real daripada teoritis.

Penolakan Rorty kepada epistemologi Barat (anti-epistemologi), metode pengetahuan (anti-metode), penolakannya kepada setiap dorongan untuk menemukan esensi kebenaran (anti-esensisialisme) dan anti-representasionisme, menurut Nielsen, pragmatisme Rorty dapat diringkas sebagai pandangan yang anti-teori, yaitu memperlihatkan ketidakpercayaannya yang mendalam terhadap teori (Nielsen, 2006: 128) dan segenap kajian-kajian yang ingin 
mengembangkannya. Melalui pragmatisme, Rorty hendak menegaskan dimensi konkret hidup manusia, yakni kebutuhan dan kepentingannya sebagai orientasi filsafatnya.

\section{Kontingensi dan Fallibilitas Kebenaran}

Khazanah epistemologi Barat yang ingin meletakkan dasar pengetahuan yang kokoh, tetap, abadi, dan final sebagai jaminan kebenaran melalui upaya penyelidikan teoritis, adalah cerminan etos filsafat Barat yang ingin menggenggam kepastian dan kesempurnaan pengetahuan. Descartes, Locke, dan Kant dengan ide epistemologi mereka masing-masing ingin menyediakan batasan teoritis yang mesti dipenuhi agar pengetahuan (kebenaran) yang asli dan sejati dapat dimungkinkan. Namun, bagi Rorty teori pengetahuan mereka (bahkan juga Plato) mencerminkan upaya keras para filsuf untuk menyingkirkan keterbatasan (PRI 297). Pengetahuan tidak boleh salah sebab jika demikian, pengetahuan berwatak terbatas. Ia tidak lagi universal dan absolut, melainkan partikular dan relatif.

Pragmatisme Rorty yang anti-teori, menolak proyek epistemologi Barat, memperlihatkan ketidaksetujuan Rorty terhadap ambisi epistemologi Barat yang ingin meniadakan keterbatasan (contingency) dunia. Alih-alih menyingkirkan keterbatasan, pragmatisme Rorty justru menerimanya sebagai bentuk antitesis terhadap wawasan epistemologi Barat. Dengan mengakui keterbatasan sebagai nilai intrinsik dunia, pragmatisme turut mengakui warisan tradisi masyarakat dan menerima rekan-rekan yang berasal dari pelbagai macam latar belakang sebagai sumber batasan hidup (PRI 297). Artinya, jika manusia mengakui bahwa realitas memiliki titik batas, hal itu tidak terletak pada faktor teoritis, melainkan kepada praksis: sikap dan cara hidup manusia. Perkembangan hidup masyarakat tidak dibatasi oleh kekekalan hukum teori, melainkan dibatasi oleh praksis rekan-rekan yang memiliki jati diri keterbatasannya sebagai manusia (PSH xxxi).

Oleh Rorty manusia diajarkan untuk melepaskan keinginan merengkuh kesempurnaan dan finalitas pengetahuan. Manusia didorong olehnya untuk melepaskan "kenyamanan metafisis" (PRI 297). Yang pokok bagi kaum pragmatis, menurut Rorty, bahwa 
manusia mesti memiliki loyalitas terhadap sesama, membangun kebersamaan dalam komunitas sosial, mengembangkan solidaritas dengan rekan-rekan untuk menghadapi tantangan dunia di tengah kemajemukan tradisi dan warisan ajaran intelektual yang sarat dengan keterbatasan, dan tidak lagi berhasrat memastikan dan menyelidiki bobot kebenaran pengetahuan atau nilai-nilai kepercayaan sebagai suatu kajian akademik teoritis. Dengan mengakui keterbatasan, Rorty menyakini bahwa tidak ada pengetahuan atau kebenaran yang tidak dapat salah.

Tidak ada kebenaran final yang mungkin lahir dari jati diri dunia yang terbatas sehingga pengetahuan manusia berpotensi salah/keliru. Dalam perspektif pragmatisme, pengetahuan, kebenaran atau nilai kepercayaan manusia memuat potensi falibilitas (PRI 297298) sehingga terbuka untuk direvisi. Mengakui kemungkinan dapat salah/kelirunya pengetahuan, seperti diulas oleh Nielsen, berarti bahwa dunia niscaya tidak akan pernah memiliki dasar kebenaran yang tetap, absolut, universal, tak terpatahkan, dan final sebagai standar baku orientasi dan penilaian dalam hidup manusia (Nielsen, 2006: 134).

Menyadari sifat fallible pengetahuan/kebenaran sama halnya dengan bersikap skeptis (skeptisisme ringan/mild skepticism) bahwa tidak ada segala sesuatu yang pasti dari dunia yang konstan berubah sehingga manusia perlu untuk meragukan, menyelidiki bahkan merevisi segala klaim kebenaran yang dihadapi, termasuk ajaran yang sangat mengakar di dalam masyarakat sekalipun (Nielsen, 2006: 135). Dengan mengakui keterbatasan dan falibilitas dunia, yang menyadari tidak ada pengetahuan, ajaran kebenaran dan posisi keyakinan yang fixed (tetap) dan final, yang merangsang sikap skeptisme, lantas bagaimana orang pragmatis menghadapi, di satu sisi kompleksitas realitas yang berubah-ubah, sementara di sisi lain, ia mesti memperjuangkan tujuan hidupnya? Nielsen menuliskan bahwa manusia jangan pernah memosisikan diri sebagai pihak yang sudah menggenggam pandangan dunia yang final dan merasa cukup diri sebab tidak ada wawasan kebenaran atau nilai keyakinan yang tetap dan pasti benar dalam konteks historis konkret apapun. Oleh karena itu, manusia mesti selalu terjaga untuk merevisi pandangan, 
menenun kembali jaring-jaring kepercayaan, bahkan memiliki alam pikir baru demi pengembangan hidup, kendati di dalam proses itu, keterbatasan sebagai manusia (merasa lelah, bosan, tidak sabar dan kosong) tak dapat terelakkan.

Namun, yang mendasar bahwa tidak ada kebenaran final, "kosa kata terakhir" dalam manusia pragmatis (Nielsen, 2006: 136). Dengan kata lain, pragmatisme Rorty justru mengajak kita untuk bersedia mengakui keterbatasan dan falibilitas pengetahuan dan nilai-nilai keyakinan kita, dan merevisinya tidak dengan mematuhi aturanaturan teoritis sebagai batasan di luar dimensi kemanusiaan individu ("nonhuman constraints") yang ahistoris, tetapi dengan menggali nilainilai yang lahir dari praksis rekan-rekan sesama sebagai sumber panduan dalam merevisi keterbatasan dan kesalahan pandangan (PRI 297-298). Dalam arti ini, pragmatisme Rorty tidak saja merangkul kontingensi dan falibilitas, tetapi juga berbobot historis (Nielsen, 2006: 134) bahwa pengetahuan, nilai kebenaran dan kepercayaan kita dimungkinkan berkembang seturut tuntutan perkembangan zaman, dan karena itu terbuka terhadap perubahan (revisi). Merasa nyaman dengan nilai kebenaran yang diyakini, dan karena itu menyingkirkan sikap kritis, adaptif, dan revisionis di tengah dunia yang dinamis, sesungguhnya adalah ilusi yang dapat menggilas.

\section{Orientasi Kepada Dimensi Praktis-Konkret}

Kritik Rorty terhadap epistemologi Barat yang tidak hanya memproduksi asas kebenaran pengetahuan yang kokoh, terpercaya, dan tak dapat salah sampai kapan pun sebagai jaminan kebenaran asli dan sejati, tetapi turut membangun moralitas masyarakat yang berambisi menggenggam kebenaran absolut dan final, adalah ekspresi Rorty yang dengan tepat menyasar kepada atmosfer teoritis yang terbentuk dari penyelidikan epistemologi Barat. Rorty mengritik proyek investigasi pengetahuan yang dirintis di Barat sejak abad ke 17 karena melihat fokus kajian di dalamnya sebagai "problem palsu" yang bernaung di dalam wilayah teoritis; wilayah yang sama sekali tidak real. Bahkan Rorty sejak awal mengidentifikasi problem pengetahuan yang ingin diatasi oleh epistemologi Barat modern 
sebagai persoalan yang memuat dimensi keabadian ("perennial, eternal problems", PMN 3) yang tidak menyentuh dimensi hidup konkret.

Dengan pragmatisme, Rorty menjungkirbalikkan motivasi theoria (teori) yang sarat dengan prosedur normatif sebagai "batasan abadi" demi kebenaran sejati dan tidak menipu, dan menggantinya dengan motivasi phronesis (tindakan) yang fokus kepada dimensi realkonkret hidup manusia, yakni kebutuhan dan kepentingan individu, dan cara memenuhinya yang dibatasi oleh praksis hidup individu lain atau masyarakat. Inilah esensi pragmatisme Rorty yang secara historis berakar kepada pragmatisme James dan Dewey yang lebih dahulu meletakkan pengalaman dan kepentingan individu dalam hidup konkretnya sebagai dasar pragmatisme.

Dengan kata lain, pragmatisme Rorty memuat ciri khas mendasar lainnya (selain dari ketiga ciri yang telah dijelaskan sebelumnya), yaitu berorientasi kepada kebutuhan hidup manusia sebagai ekspresi dimensi hidup konkret yang diatur oleh batasanbatasan real-praktis, alih-alih ideal-teoritis, di dalam sikap dan tindakan individu yang lain. Di dalam konteks tersebut, pragmatisme Rorty dengan tegas menyatakan realitas tidak dikaji atas dasar tingkat representasi pengetahuan manusia (PSH xxii) dan berujung kepada pemeringkatan jenis-jenis pengetahuan berdasar kepada tingkat kemampuannya dalam mencerminkan realitas secara akurat. Sebaliknya Rorty menegaskan bahwa realitas dikaji dari efek kegunaan yang mungkin diproduksi dari suatu nilai pengetahuan atau ajaran kebenaran yang diyakini, yaitu realitas mana yang memiliki efek manfaat lebih atau kurang dalam agenda pemuasan kepentingan individu (PSH xxii).

Bagi Rorty penelitian tentang manusia, hidup dan dunianya yang direduksi kepada upaya membongkar realitas atas asas representasi realitas yang akurat, sudah harus dihentikan, dan sebaliknya harus mulai terarah kepada kajian faktor kegunaan (PSH xxvi) dari suatu ajaran kepercayaan atau kebenaran yang lazim berkembang dalam masyarakat, yaitu faktor-faktor yang dapat memuaskan kebutuhan manusia yang memang berhak untuk dipenuhi (PSH xxviii). Artinya, dimensi kebutuhan dan kepentingan konkret individu sebagai sumber orientasi pragmatisme selalu 
bermuara kepada perkara cara pemenuhan terhadapnya (PSH xxvii) dan tentu saja turut dipikirkan dalam pragmatisme.

\section{KONSEKUENSI PRAGMATISME TERHADAP FILSAFAT}

Apa yang telah diterangkan sejauh ini, karakteristik pragmatisme Rorty terbentuk dari sikap kritis dan konfrontasinya terhadap fokus kajian epistemologi Barat modern yang menjamin bobot kesahihan atas kebenaran pengetahuan manusia. Rorty menilai proyek filsafat sebagai epistemologi yang telah dirintis sejak abad ke 17 oleh Descartes, Locke dan Kant sebenarnya hanya berkutat di dalam dunia teoritis belaka. Oleh karena itu, dimensi teoretis dalam horison pragmatisme Rorty benar-benar sepenuhnya tersingkir. Pragmatisme Rorty menghendaki agar penyelidikan epistemologi (sebagai suatu cabang filsafat) tentang fungsi representasi dan fondasi pengetahuan sebagai suatu kajian teoritis, harus diakhiri. Dan sebagai gantinya menurut Rorty, filsafat harus segera beralih kepada problem konkret-praktis manusia, yaitu filsafat mesti mengembangkan diri di dalam batasan kepentingan dan kebutuhan konkret manusia.

Hal ini berarti pragmatisme berorientasi kepada dimensi real dan praktis individu, yang turut menghasilkan konsekuensi tertentu kepada fungsi dan bentuk filsafat itu sendiri dalam pragmatisme Rorty. Saya melihat ada dua konsekuensi filsafat dalam wawasan pragmatisme Rorty dalam bukunya Philosophy and the Mirror of Nature (PMN) dan Philosophy and Social Hope (PSH) :

\section{Filsafat Sebagai Sarana}

Kepentingan dan kebutuhan individu sebagai fokus orientasi pragmatisme tak dapat dipisahkan dari pengaruh Darwinisme. Dalam pemahaman Darwinian dengan pendekatan biologisnya, sebagaimana dipahami Rorty, manusia adalah organisme yang hidup di dalam alam, berinteraksi dengannya dan berupaya untuk mengatasi segala tantangan dari lingkungan sekitarnya. Untuk tetap mempertahankan dan mengembangkan hidupnya, manusia mesti mengatasi lingkungan di sekelilingnya. Oleh karena itu, manusia memerlukan pelbagai bentuk alat (tools) untuk memenuhi kepentingannya itu. 
Manusia mengembangkan alat-alat sebagai sarana agar dapat memperoleh kenikmatan lebih banyak dan mengurangi penderitaan. Bahasa dianggap Rorty sebagai salah satu alat yang diciptakan dan dikembangkan oleh manusia (sebagai binatang yang cerdas) sebagai sarana kehidupannya. Bagi Rorty apapun jenis alatnya, baik itu senjata, palu, bahasa, pengetahuan, maupun ajaran kepercayaan, itu semua digunakan di dalam interaksi manusia dengan lingkungannya. Manusia jelas memerlukan alat untuk mengatasi hidupnya (PSH xxiii \& xxvii). Dengan pengertian ini, pragmatisme Rorty jelas berpijak kepada dimensi konkret dan praktis manusia. Dalam arti itu, pengetahuan dalam pragmatisme Rorty tidak lagi berurusan dengan perkara merepresentasikan realitas secara akurat untuk menjamin kebenaran sejati, melainkan sebagai sarana untuk mengatasi realitasnya (Nielsen, 2006: 132).

Ketika dulu dipahami bahwa mataharilah yang mengelilingi bumi, lalu kemudian muncul klaim bahwa justru bumi yang mengitari matahari sebagaimana kenyataan sebenarnya, dalam perspektif pragmatis, hal itu jangan dimengerti secara representasionis, bahwa pengetahuan manusia mampu mencerminkan realitas dengan akurat sebagai argumen yang teoritis, melainkan karena manusia telah memiliki jenis alat yang lebih baik daripada yang dimiliki para pendahulu yang memungkinkan pengetahuan manusia lebih maju ( $\mathrm{PSH} x x v)$.

Dalam arti praktis itu pula, meski tidak secara eksplisit diterangkan oleh Rorty, filsafat dapat dipahami sebagai alat untuk mengatasi kepentingan hidupnya dan berinteraksi dengan lingkungannya. Pengertian praktis pragmatisme sudah selalu membawa dimensi alat di dalamnya. Dan oleh karena fokus pragmatisme tertuju kepada upaya pemenuhan kebutuhan hidup manusia dan niscaya memerlukan alat, konsekuensinya filsafat adalah salah satu alat (sarana) yang diperlukan oleh manusia untuk memenuhi tujuan dan kepentingannya. Secara spesifik, filsafat "tidak lagi berkutat kepada konsepsi-konsepi representasi untuk mencerminkan realitas dengan tepat-akurat sebagai penyelidikan apriori teoritis", sebaliknya filsafat dapat dimengerti sebagai "suatu cabang dalam jaringan relasi kausal yang mengikat manusia sebagai 
organisme dengan lingkungannya" yang berfungsi sebagai alat kehidupannya (PSH xxiii). Yang kemudian perlu dipikirkan adalah bagaimana manusia menggunakan pelbagai sarana yang telah diciptakan manusia untuk perkembangan segala bidang kehidupannya (katakanlah dalam bidang politik atau teknologi) (PSH xxv). Maka dari itu, jika filsafat adalah sarana praktis dalam hidup manusia yang berfungsi mendukung proses interaksi manusia dengan lingkungannya dan dapat memenuhi kepentingannya, bagaimana secara konkret filsafat dikembangkan oleh Rorty?

\section{Filsafat Pengajaran}

Rorty memiliki pemahamannya yang spesifik tentang bentuk dan fokus kajian filsafat. Baginya filsafat tidak dikembangkan dari bentuknya sebagai disiplin ilmu yang sistematis atau "filsafat sistematis" (systematic philosophy), melainkan sebagai "filsafat pengajaran" (edifying philosophy) (PMN 368-372). Sebagai sarana untuk menghadapi hidupnya, interaksi manusia dengan lingkungannya, filsafat mesti memiliki bentuk edifying tersebut, dan bukan secara tradisional dalam tradisi representasionis dan fondasionalis abad 17. Filsafat dalam bentuk tradisional itu, dalam analisis Nielsen, berpijak kepada filsafat Plato atau Kant yang terpusat kepada pertanyaan hakikat realitas di dalam konsepsi-konsepsi abstrak dan normatif, seperti kebenaran, rasionalitas dan kebaikan, yang disertai ajakan moral untuk menaatinya (Nielsen 2006, 128).

Filsafat tradisional yang mengambil bentuk kajian epistemologi dan metafisika yang berhasrat menjamin kebenaran pengetahuan manusia dan memberi kedalaman makna kepadanya tentang hakikat realitas secara mendasar dan menyeluruh, menurut Rorty termanifestasi ke dalam filsafat sistematis. Dengan menyediakan prinsip-prinsip dasar yang memastikan kebenaran pengetahuan yang sahih, filsafat sistematis meminta manusia untuk menyesuaikan diri (konformitas) seturut dengan ajaran yang sudah ditetapkan oleh para filsuf arus utama, (PMN 367-368) seperti Plato, Descartes, Locke dan Kant.

Filsafat yang dikembangkan oleh pragmatisme Rorty, berlawanan dengan filsafat sistematis dan disebutnya dengan filsafat 
pengajaran. Dengan bentuk ini, filsafat sama sekali tidak menggali kedalaman epistemologi atau metafisika, melainkan menurut Nielsen, dengan mengacu kepada filsuf Wilfrid Sellars, menurut Rorty, filsafat adalah kajian yang berupaya memahami kompleksitas realitas, memahami kaitan realitas yang satu dengan lainnya melalui pengertian yang seluas-luasnya dan sekaya mungkin (Nielsen, 2006: 129). Dalam arti itu, di tengah pelbagai nilai kebenaran dan kepercayaan, filsafat berfungsi membantu seseorang untuk melakukan koherensi, menemukan kesesuaian argumen klaim kebenaran yang satu dengan lainnya, menggali pengertian dari pelbagai pengetahuan dan nilai kepercayaan masyarakat, menyelidiki keterbatasan dan falibilitasnya, semuanya ditempuh dalam rangka memajukan hidup dan memuaskan kepentingannya sebagai dimensi konkret-praktis hidupnya, dan tidak berintensi sama sekali untuk mendalami tema-tema dalam filsafat tradisional yang sebenarnya merupakan problem palsu filsafat (Nielsen, 2006: 129). Itu artinya pula, filsafat pragmatisme Rorty mengakui pluralisme gagasan, nilai dan kepentingan sebagai unsur-unsur yang membentuk manusia sebagai insan konkret.

Filsafat pengajaran yang dimaksud Rorty terwujud dalam filsafat John Dewey, Ludwig Wittgenstein dan Martin Heidegger. Dewey dengan ajaran pragmatismenya yang memihak kepada dipenuhinya kepentingan individu, Wittgenstein yang mengajarkan bahwa bahasa tidak lagi berurusan dengan perkara isomorfis (satu proposisi mengacu kepada satu objek real), melainkan memuat aturan-aturan berbahasa (language games) yang berkembang secara arbitrer sesuai dengan kesepakatan masyarakat tertentu dan karena itu bahasa turut mencerminkan suatu bentuk kehidupan tertentu yang ada di masyarakat, dan Heidegger yang fokus menggali manusia sebagai subjek eksistensial yang mengatasi faktisitasnya (eksistensinya yang ada begitu saja) adalah para filsuf pengajaran yang dijadikan contoh oleh Rorty (PMN 368). Ketiganya menyediakan pengertian-pengertian filosofis yang diajarkan kepada masyarakat agar tidak lagi terbelenggu dari sikap dan kosakata-kosakata metafisis dan epistemologis filsafat tradisional (Nielsen, 2006: 134). 
Filsafat Dewey, Wittgenstein dan Heidegger dipilih sebagai acuan model filsafat pengajaran yang Rorty maksud karena ketiganya menitikberatkan kepada keseluruhan dimensi manusia sebagai subjek konkret yang memiliki keanekaragaman nilai, tujuan dan problematika yang hanya bisa diselesaikan dengan gaya yang konkret pula, yang tidak terpaku kepada satu pakem wawasan yang mutlak dan tetap. Ketiganya, menurut Rorty, menertawakan pemahaman filsafat sistematis/tradisional yang menghendaki suatu tolok ukur universal di dalam bahasa-bahasa konseptual yang final. Jika filsafat sistematis/tradisional mengembangkan wawasannya dengan membangun argumentasi yang runut dan sistematis (konstruktif) sebagai disiplin ilmiah sejajar dengan ilmu-ilmu empiris (alam maupun sosial), dan asas-asas di dalamnya dapat berlaku kekal abadi, lain halnya dengan filsafat pengajaran yang justru berbobot reaktif yang hendak meruntuhkan hegemoni filsafat sistematis demi generasi selanjutnya yang lebih maju berkembang (bdk. PMN 369-371).

Meski tidak menunjuk secara jelas, generasi yang dimaksud Rorty adalah angkatan kaum masyarakat yang tidak berwatak dogmatis karena ketaatannya kepada norma-norma yang memungkinkan kebenaran pengetahuan. Ketaatan kepada prosedur formal apriori yang berlaku abadi sebagai konsepsi ahistoris sejajar dengan ajaran agama yang justru dapat mematikan rasa ingin tahu dan keheranan manusia terhadap realitas. Filsafat pengajaran, menurut Rorty, hendak menjaga dorongan keheranan manusia agar tetap terbuka lebar, yang bahkan dapat dirangsang oleh puisi sekalipun (PMN 370) untuk memastikan nilai kepercayaan dan kebenaran yang bermanfaat bagi hidupnya.

Dengan kata lain, dalam rangka pemuasan kepentingan dan tujuan individu, memperoleh manfaat sebesar-besarnya, filsafat pengajaran adalah bentuk dan fungsi filsafat yang sesuai dengan orientasi pragmatisme Rorty yang berpusat kepada dimensi konkretpraktis hidup manusia. Filsafat pengajaran adalah bentuk dan fungsi filsafat yang memadai sebagai sebuah konsekuensi karena keberpihakan pragmatisme kepada pencarian manfaat dan pemenuhan kepentingan individu seluas-luasnya sejauh pemuasan kepentingan orang lain tidak terhalangi sebagai asas batasannya. 
Filsafat pengajaran tidak menawarkan pandangan disiplin keilmuwan yang teoritis, melainkan ajaran-ajaran yang dapat membantu dan memungkinkan seseorang untuk mengatasi kehidupannya, memikirkan cara untuk mendatangkan manfaat bagi dirinya dan dapat memenuhi kepentingannya. Ini artinya, filsafat pengajaran adalah "filsafat tanpa cermin" yang tidak mendorong orang untuk berkontemplasi mengkaji konsep-konsep yang merepresentasikan realitas, melainkan merangsang seseorang untuk bertindak dalam hidupnya karena pragmatisme sebagaimana dipikirkan Rorty, hendak membentuk seseorang menjadi manusia praktis, bukan manusia teori.

\section{SIMPULAN}

Sebagai konsepsi filosofis intelektual, pragmatisme bermula dan berkembang sejak abad ke-19 di AS oleh tokoh-tokoh penting seperti William James dan John Dewey. Pemikiran kedua tokoh ini mempengaruhi pemikiran Richard Rorty dalam membangun gagasan pragmatisme yang sarat dengan kritik terhadap metafisika dan epistemology Barat modern.

Dalam kritiknya, Rorty melihat secara tajam bahwa sejak Descartes, Locke dan Kant pada abad ke-17, filsafat sistematis dalam tradisi epistemologi dan metafisika Barat hanya berkutat kepada problem fondasi dan fungsi representasi pengetahuan sebagai suatu aparatus konseptual yang mendasari kebenaran pengetahuan manusia. Bagi Rorty, proyek filsafat sebagai epistemologi yang mulai dibangun sejak abad ke-17 di Barat semacam itu adalah cara mengembangkan filsafat "di dalam jalur sains yang aman" (PMN 137) demi kedudukan filsafat yang sejajar dengan sains guna menyediakan kepastian dan kebenaran pengetahuan. Namun, dalam kritik Rorty, fokus proyek epistemologi Barat kepada fungsi fondasi dan representasi realitas yang diemban oleh pengetahuan manusia, sebenarnya hanya mengembangkan dunia teori yang sama sekali tidak bermanfaat bagi realitas konkret hidup manusia.

Kritik keras Rorty terhadap gaya epistemologi Barat yang sibuk meletakkan fondasi dan mempertajam fungsi pengetahuan sebagai representasi (cermin) alam adalah pijakan baginya untuk 
merumuskan filsafat baru yang ia pilih di jalur pragmatisme. Pragmatisme Rorty adalah sebuah orientasi baru filsafat yang terarah kepada dimensi konkret-praktis hidup manusia yang mengakui keragaman nilai dan kepentingan, adanya kemungkinan bahwa gagasan dan pengetahuan manusia dapat salah atau keliru (fallible), serta segala upaya mencapai tujuan sejauh kepentingan orang lain tidak dirugikan. Dengan bobot pengertian seperti itu, pragmatisme Rorty, dengan kata lain, adalah usaha melawan hegemoni filsafat tradisional Barat yang lazim terpusat pada usaha penemuan syaratsyarat pengetahuan; pragmatisme Rorty menyingkirkan kelaziman itu semua dan pada gilirannya menghasilkan sifat-sifat antiesensialisme, anti-epistemologi, kontingensi dan fallibilitas kebenaran, dan tentu saja berorientasi kepada dimensi konkretpraktis hidup manusia dalam tubuh pragmatisme Rorty.

Dengan orientasi praktis ini, pragmatisme Rorty mendorong kepada dimensi aksi, daripada kontemplasi yang dahulunya lazim dalam wawasan epistemologi Barat. Konsekuensinya, filsafat dalam pragmatisme Rorty mengambil bentuk filsafat pengajaran (edifying philosophy) yang mengacu kepada filsafat Dewey, Wittgenstein dan Heidegger di mana pemikiran ketiganya terpusat kepada eksplorasi pelbagai dimensi manusia sebagai subjek eksistensial konkret. Hasilnya, secara gamblang filsafat pengajaran dalam pragmatisme Rorty meninggalkan fokus filsafat tradisional sistematis karena sama sekali tidak berfaedah bagi hidup konkret manusia. Dalam pragmatisme, filsafat tidak lagi melayani tujuan abstrak-teoritis, melainkan berfungsi sebagai sarana (alat) yang merangsang aksi seseorang untuk memuaskan kepentingan dan memajukan hidupnya. Secara menyeluruh, pragmatisme Rorty sesungguhnya adalah manifestasi dukungannya terhadap dunia konkret hidup manusia dengan segala aneka nilai, gagasan, dan tujuan di dalamnya.

\section{DAFTAR PUSTAKA}

Jackson, Philip W, 2006, "John Dewey" dalam A Companion to Pragmatism, ed. John R. Shook \& Joseph Margolis, hal 54-65, UK, USA \& Australia: Blackwell Publishing. 
Nielsen, Kai, 2006, "Richard Rorty" dalam A Companion to Pragmatism, ed. John R. Shook \& Joseph Margolis, hal 127-137, UK, USA \& Australia: Blackwell Publishing.

Rorty, Richard, 1979, Philosophy and the Mirror of Nature, New Jersey: Princeton University Press. 1980 "Pragmatism, Relativism and Irrationalism" dalam Human Knowledge Classical and Contemporary Approaches Third Edition, ed. Paul K. Moser \& Arnold Vander Nat, Oxford University Press, hal 294-303.

--_---, 1999 Philosophy and Social Science, Penguin Books.

Russell, Bertrand, 1972, The History of Western Philosophy, New York: A Touchstone Book Simon \& Schuster, INC.

Shook, John R \& Joseph Margolis [ed], 2006, A Companion to Pragmatism, USA, UK, Australia: Blackwell Publishing.

Suckiel, Ellen Kappy, 2006, “William James" dalam A Companion to Pragmatism, ed. John R. Shook \& Joseph Margolis, hal 30-53, UK, USA \& Australia: Blackwell Publishing.

Sudarminta, J, 2002 Epistemologi Dasar Pengantar Filsafat Pengetahuan, Yogyakarta: Penerbit Kanisius.

Tartaglia, James, 2007, Rorty and the Mirror of Nature, London \& New York: Routledge.

Cohen, Patricia, "Richard Rorty, Philosopher Dies at 75", diakses di www.newyorktimes.com 17 Februari 2017 pukul 20:00 WIB. 